\title{
Assessment of Hepatoprotective and Antioxidant Activities of Ethanolic Extract of Tephrosia villosa in Albino Rats
}

\author{
Chakali Ayyanna ${ }^{*}$, Boyini Mounika', Sree Sudha Tanguturi Yella², Pugazhenthan Thangaraju ${ }^{2}$ \\ 'Department of Pharmacology, CES College of Pharmacy, Kurnool, Andhra Pradesh, INDIA. \\ 2Department of Pharmacology, All India Institute of Medical Sciences, Raipur, Chhattisgarh, INDIA.
}

\begin{abstract}
Objectives: To Study the hepatoprotective and antioxidant activity of the whole plant, ethanolic extract of Tephrosia villosa (EETV). Methods: Hepatoprotective effect of EETV is studied against carbon tetrachloride $\left(\mathrm{CCl}_{4}\right)$ and paracetamol-induced hepatotoxicity in rats. Individual rats received EETV doses of 200 and $400 \mathrm{mg} / \mathrm{kg}(\mathrm{w} / \mathrm{w})$ for seven days, respectively. On the $7^{\text {th }}$ day, induced hepatotoxicity in all rats of all groups by $1.25 \mathrm{ml} / \mathrm{kg}$ (i.p) $\mathrm{CCl}_{4}$ and paracetamol $1 \mathrm{gm} / \mathrm{kg} / \mathrm{p}$.o. Determining effects of ETEV on antioxidant activity, SGOT, SGPT, ALP, and direct bilirubin were, and also performed a histopathological exam of the liver sections. Results: The extract prevented the exhaustion of glutathione and catalase levels and increased lipid peroxidation levels against $\mathrm{CCl}_{4}$ induced and Paracetamol liver injury in rats. By histopathological evidence, EETV also significantly
\end{abstract}

decreased biochemical levels of liver enzymes with high hepatoprotection at $200 \mathrm{mg} / \mathrm{kg}$. Conclusion: Present study results strongly reveal that EETV has hepatoprotective and antioxidant activity against $\mathrm{CCl}_{4}$ and paracetamolinduced hepatic impairment in experimental animals

Key words: Tephrosia villosa, Hepatoprotective, Antioxidant, Carbon tetrachloride, Paracetamol, Silymarin.

Correspondence

Dr. Sree Sudha TY,

Senior resident, Department of Pharmacology, AlIMS, Raipur, Chhattisgarh, INDIA. Email id: sudhanmcmbbs@gmail.com

DOI: 10.5530/jyp.2021.13.47

\section{INTRODUCTION}

The Liver plays a vital role in the secretion of bile, storage of vitamins, xenobiotics, metabolism of fats, carbohydrates, and proteins. In the liver, drug detoxification occurs through various physiochemical phases such as oxidation, reduction, conjugation, sulfation, acetylation, etc. The liver injury is initiated by various toxic agents produced by distortion of metabolic functions, chemicals, alcohol, viruses, or bio-activation to chemically reactive metabolites. ${ }^{1-3}$ These metabolites can be free radicals that contain unpaired electrons. The oxygen radicals such as superoxide, hydroxyl radicals, and non-free radical species $\left(\mathrm{H}_{2} \mathrm{O}_{2}\right)$, and singlet oxygen are generated in many redox processes of normal physiochemical pathways. ${ }^{4,5}$ Antioxidants trap and destroy these radicals. Vitamin deficiency, overproduction of free radicals and reduced antioxidants were considered predisposed factors of oxidative stress. ${ }^{5}$ Over the past few years research on oxidants and antioxidants has shown a link between most diseases such as cardiovascular disease, cancer, osteoporosis, degenerative diseases, etc., and production of reactive oxygen species (ROS) along with oxidative stress. ${ }^{6-8}$ Hepatitis is one of the most prevalent diseases in the world. ${ }^{9}$ Around 20,000 deaths and 250,000 new cases of liver diseases have been reported every year. ${ }^{10}$ Oxidative stress plays a vital role in the development of liver diseases. Free radicals primarily act by binding the unsaturated fatty acids in biomembranes, which results in membrane lipid peroxidation, decrease in membrane fluidity, reduction of enzymes and receptor activity, and damage to the membrane protein. All these factors trigger cell inactivation, and death occurs. ${ }^{4,5}$ Therefore, antioxidants can be used to reverse the harmful and pathological actions of free radicals. Countless xenobiotics are known to cause hepatotoxicity; one among them is $\mathrm{CCl}_{4}$ that may cause lipid peroxidation. ${ }^{11}$

Several medicinal preparations in the Indian system of medicine (Ayurveda) have been using as effective hepatoprotective agents. Because of this, several medicinal preparations and medicinal plants mentioned in Ayurveda are being investigated to treat various liver disorders. ${ }^{12,13}$ As far as our literature survey is concerned, extracts from different parts of this plant have been reported to possess various biological activities. Still, no report has been published about the hepatoprotective activity of Tephrosia villosa. Therefore, in this study, an attempt has been made to evaluate the hepatoprotective activity and an antioxidant profile of Tephrosia villosa against Carbon tetrachloride $\left(\mathrm{CCl}_{4}\right)$ and Paracetamol induced hepatotoxicity in albino rats.

\section{MATERIALS AND METHODS}

\section{Plant Material}

The whole Tephrosia villosa (Family: Leguminosae) was collected after the authentication by Dr. K. Madhava Chetty, Plant Taxonomist, Assistant Professor, Department of Botany, Sri Venkateswara University, Tirupati, Andhra Pradesh, India. The leaves were collected from Tirumala hills. The voucher number is 1146 .

\section{Extraction}

The collected whole plant of Tephrosia villosa was washed thoroughly with water and dried in the shade. The dried powder was defatted with n-hexane using Soxhlet apparatus. The defatted powder was dried at room temperature and then extracted using $95 \%$ ethanol by continuous hot percolation until the clear liquid was obtained in the siphon tube. After completing the extraction, the solvent was removed by steam distillation method to get a solid mass. After obtaining the Whole plant of Tephrosia villosa extract, the phytochemical screening was carried out to identify the various components in the extract. 


\section{Experimental Animals}

The study was carried out after obtaining the Institutional Animal Ethics Committee approval number - IAEC/ CESCOP/ 2018-03. Albino Wistar rats were used in the study. The animals were procured from CES College of Pharmacy, Chinnatekur, Kurnool. Animals were housed in polyacrylic cages, maintained under standard conditions of $18^{\circ} \mathrm{C} \pm 2^{\circ} \mathrm{C}$ and $12 \mathrm{hr}$ light / dark cycles. Animals have free access to a standard chow diet and water, ad libitum.

\section{Acute Toxicity Experiment}

The acute toxicity test was performed according to the Organization of Economic Cooperation and Development guidelines $423 .{ }^{14}$ The animals were fasted overnight before the experiment. Albino rats $(n=3)$ were divided into five groups, and ethanolic extract of Tephrosia villosa (EETV) was administered with different doses. The extract was administered orally in increasing doses up to $2000 \mathrm{mg} / \mathrm{kg}$. After $72 \mathrm{hr}$ animals were found to be well tolerated. There was no mortality and no signs of toxicity. Hence $1 / 10^{\text {th }}$ part of the dose was selected for the hepatoprotective study. So, two dose levels, i.e., $200 \mathrm{mg} / \mathrm{kg}$ (low dose) and $400 \mathrm{mg} / \mathrm{kg}$ (high dose), were selected for the biological study.

\section{Hepatoprotective Study}

The rats were divided into five groups having six animals in each group as follows,

\section{$\mathrm{CCl} 4$ induced hepatotoxicity in albino rats}

Group 1: Animals were administered with vehicle (Carboxymethyl cellulose [CMC] 3\%, p.o.) for seven days.

Group 2: Hepatotoxic group - the animals were administered with vehicle (CMC 3\%, p.o.) for six days. On the $7^{\text {th }}$ day, the animals were treated with $\mathrm{CCl}_{4}$ at a dose of $1.25 \mathrm{ml} / \mathrm{kg}$ I.P.

Group 3: Animals were administered a standard hepatoprotective drug such as silymarin for six days at a dose of $100 \mathrm{mg} / \mathrm{kg}$, p.o. On the $7^{\text {th }}$ day, the animals were treated with $\mathrm{CCl}_{4}$ at a dose of $1.25 \mathrm{ml} / \mathrm{kg}$ I.P.

Group 4: Animals were administered with EETV at a low dose, $200 \mathrm{mg} / \mathrm{kg}$ p.o. for six days, and on the $7^{\text {th }}$ day, the hepatotoxicity was induced with $\mathrm{CCl}_{4}$ at a dose of $1.25 \mathrm{ml} / \mathrm{kg}$ I.P.

Group 5: Animals were administered with EETV at a high dose, $400 \mathrm{mg} / \mathrm{kg}$ p.o. for six days, and on the $7^{\text {th }}$ day, the hepatotoxicity was induced with $\mathrm{CCl}_{4 \text { at }}$ a dose of $1.25 \mathrm{ml} / \mathrm{kg}$ I.P.

On the $7^{\text {th }}$ day, after $48 \mathrm{hr}$ of $\mathrm{CCl}_{4}$ administration, the blood was collected through retro-orbital plexus for testing the SGOT, SGPT, ALP, and total bilirubin levels. Finally, animals were sacrificed, and the extracted liver was excised and rinsed in ice-cold normal saline, followed by $0.15 \mathrm{M}$ Tris- $\mathrm{HCl}$ ( $\mathrm{pH}$ 7.4) blotted dry and weighed. A $10 \% \mathrm{w} / \mathrm{v}$ of homogenate was prepared in $0.15 \mathrm{M}$ Tris-HCl buffer. A part of homogenate after precipitating proteins with trichloroacetic acid (TCA) was used for estimation of glutathione by the method of Ellman. The rest of the homogenate was centrifuged at $15000 \mathrm{rpm}$ for $15 \mathrm{~min}$ at $4^{\circ} \mathrm{C}$. The supernatant thus obtained was used for the estimation of catalase (CAT) activities, and it was measured by the method of Aebi. The levels of Lipid peroxidation level (LPO) were also observed along with the biochemical liver enzymes (SGOT, SGPT, ALP, and Bilirubin). ${ }^{15}$

\section{Paracetamol induced hepatotoxicity in albino rats}

Group I - Normal

Group II -- Paracetamol 1gm/kg body weight p.o was administered to the animals on the fifth.

Day.
Group III - animals were administered with silymarin in a dose of $100 \mathrm{mg} / \mathrm{kg}$ body.

Weight p.o. for seven days. On the fifth day, paracetamol was administered in a dose of $1 \mathrm{~g} / \mathrm{kg}$ body weight p.o.

Group IV - Animals were administered with a low dose of $200 \mathrm{mg} / \mathrm{kg}$ p.o. whole plant

Tephrosia villosa Extract p.o. for seven days. On the fifth day, paracetamol was administered in a dose of $1 \mathrm{~g} / \mathrm{kg}$ body weight p.o.

Group V -Animals were administered with a high dose of $400 \mathrm{mg} / \mathrm{kg}$ p.o. whole plant Tephrosia villosa extract p.o. for seven days. On the fifth day, paracetamol was administered in a dose of $1 \mathrm{~g} / \mathrm{kg}$ body weight p.o. At the end of the $7^{\text {th }}$-day treatment protocol, animals of all groups were sacrificed. Blood was collected, allowed to clot, and centrifuged at 3000rpm for $10 \mathrm{~min}$, and serum was separated. The serum levels of marked enzymes viz. ALP, SGOT, SGPT, and bilirubin (direct and total) were measured by using semi auto analyzer. All enzyme estimations were analyzed using assay kits. The liver was isolated and kept in $10 \%$ buffered formalin solution and processed for histopathological studies. ${ }^{16}$

\section{Estimation of Liver Function Markers}

Liver functions were assessed by measuring the serum levels of ALP, SGOT, SGPT, and Bilirubin by using the methods of Agappe kits.

\section{In vitro Antioxidant Activity}

The liver homogenate was used for estimating Glutathione (GSH), ${ }^{17}$ Catalase (CAT) ${ }^{18}$ and LPO.${ }^{19}$ The procedure to estimate the reduced GSH level followed the method described by Ellman. The principle involves the reaction of glutathione with Dithiobisnitrobenzoic acid (DTNB) to give a compound that has an absorption maximum at $412 \mathrm{~nm}$. CAT activity can be measured by the method of Aebi. The breakdown of hydrogen peroxide on the addition of enzyme was followed by observing the decrease in light absorption of peroxide solution in the ultraviolet (UV) region. The LPO products (as Malonaldehyde) were determined by the reaction of liver homogenate with the Thiobarbituric acid.

\section{Histopathological Assessment}

The liver from each rat was removed after dissection and preserved in $10 \%$ formalin. Liver tissues from each lobe were taken and possessed for paraffin embedding using the standard micro-technique. Sections of 5-6 $\mathrm{mm}$ were made and then stained with hematoxylin and eosin dye for photo microscopic observation. The histopathological changes were clearly evaluated.

\section{Statistical Analysis}

The data are presented as the Mean \pm SEM. The statistical significance of differences between the groups was assessed with one-way ANOVA using Tukey's multiple comparison analysis for comparing means in the GraphPad Prism 5 Software. A $P<0.05$ was considered statistically significant.

\section{RESULTS}

\section{Phytochemical Studies}

EETV showed the presence of flavonoids, alkaloids, steroidal saponins, bufadienolides, phenolics, tannins and resins, carbohydrates, proteins, and anthraquinone glycosides.

\section{Effect of EETV on Biochemical Liver Enzyme Levels}

Effect of ethanolic extract of Tephrosia villosa on biochemical parameters in Carbon tetrachloride-induced hepatotoxic rats: Rats treated with $\mathrm{CCl}_{4}$ developed a hepatic injury, observed as raised serum levels of hepatic 
enzymes like ALT, AST, ALP, and TB when compared to normal control. Pre-treatment with silymarin, the ethanolic extract had shown good protection against $\mathrm{CCl}_{4}$ induced toxicity to the liver. Significant reduction in elevated serum enzyme levels in extract-treated animals compared to toxic control animals, which is evident in Table 1.

Effect of ethanolic extract of Tephrosia villosa on biochemical parameters in paracetamol induced hepatotoxic rats: On administration of paracetamol, hepatic damage was developed. All the serum levels of hepatospecific enzymes like ALT, AST, ALP, and TB were raised when compared to normal control. Pre-treatment with silymarin, the ethanolic extract had shown good protection against Paracetamol-induced toxicity to the liver. The test indicates a significant reduction in elevated serum enzyme levels with extract-treated animals compared to toxic control animals, which is evident in Table 2.

\section{Effect of ethanolic extract of Tephrosia villosa on in vitro antioxidants studies in $\mathrm{CCl}_{4}$ and Paracetamol induced hepatotoxic rats}

Hepatic lipid peroxidation (LP), expressed as thiobarbituric acid reacting substances (TBARS), enhanced significantly in $\mathrm{CCl}_{4}$ and paracetamol toxicity (Table 3 and 4). The protective enzymes such as Superoxide dismutase (SOD) and catalase (CAT), and glutathione content in liver tissue were reduced after paracetamol administration (Table 3 and 4). Improved LP and decreased levels of SOD and CAT indicate the generation of free radicals' pressure as a characteristic of hepatic damage because of $\mathrm{CCl}_{4}$ and paracetamol toxicity. Marked decrease of these free radical scavenging enzymes, $\mathrm{SOD}$ and $\mathrm{CAT}$, with $\mathrm{CCl}_{4}$ and paracetamol were became normal on oral administration of EETV in a dose-dependent manner.

\section{Histopathology}

Histopathological evaluations (Figure 1 and 2) of single dose $\mathrm{CCl}_{4}$ and Paracetamol have shown centrilobular degeneration and necrosis of hepatic cells with dilated blood vessels (Figure 1 and 2 B) when compared to the normal/vehicle control group (Figure 1 and $2 \mathrm{~A}$ ). Concurrent administration of EETV at different doses $(200 \mathrm{mg} / \mathrm{kg}$ and $400 \mathrm{mg} / \mathrm{kg})$ preserved the normal architecture of hepatocytes, respectively, as shown in Figure 1 and 2 D.

\section{DISCUSSION}

Carbon tetrachloride and Paracetamol are used to induce liver injury in laboratory animals. The progression of hepatotoxicity to $\mathrm{CCl}_{4}$ is similar to that of intense viral hepatitis. The hepatotoxicity of $\mathrm{CCl}_{4}$ was due to its biotransformation by cytochrome P-450 to trichloroethylene free radicals. These free radicals may again react with oxygen to frame trichloroethylene peroxy radicals, which acts on the lipid layer of the endoplasmic reticulum to bring out lipid peroxidation. ${ }^{20}$ Excess of Paracetamol causes a fatal hepatic centrilobular necrosis, due to the poisonous metabolite $\mathrm{N}$-acetyl-p-benzoquinone imine (NAPQI) by the activity of cytochrome P4502E1. ${ }^{21}$ In the current evaluation, $\mathrm{CCl}_{4}$ and paracetamol administration results in raised AST levels, ALT, ALP, and bilirubin, suggestive of liver toxicity and responsible for the leakage of cellular enzymes into the blood. However, if the liver plasma membrane gets damaged, various enzymes located in the cytosol are released into the circulation..$^{22}$ Oral administration of different dosages of EETV to $\mathrm{CCl}_{4}$ and Paracetamol intoxicated animals shown gradual normalization of the AST, ALT, and ALP values. This recommends the defensive impact of the extract in improving the functional integrity of liver cells. Serum bilirubin was considered as an index for the appraisal of hepatic capacity, and its elevated levels shows hepatobiliary disease. Hepatotoxic nature of both $\mathrm{CCl}_{4}$ and Paracetamol confirmed by enhanced serum bilirubin levels after their infusion. Treatment with EETV significantly reduced total bilirubin and confirmed as hepatoprotective herb.

Hepatic lipid peroxidation (LP), expressed as TBARS (thiobarbituric acid reacting substances), significantly enhanced $\mathrm{CCl}_{4}$ and paracetamol toxicity. In contrast, the activities of protective enzymes such as Superoxide dismutase (SOD) and catalase (CAT), and glutathione content in liver tissue were brought down after paracetamol administration. Improved LP and decreased activities of SOD and CAT indicates that generation of free radicals is a characteristic of hepatic damage due to $\mathrm{CCl}_{4}$ and paracetamol. Marked decreases in the activities of these free radical scavenging enzymes, SOD and CAT, related with $\mathrm{CCl}_{4}$ and paracetamol harmfulness, were significantly switched to normal on oral administration of EETV in a dose-dependent manner showing the anti-lipid peroxidative property of the extract. Histopathological assessment of liver segments of the standard control group showed typical cellular architecture with distinct hepatic cells. However, characteristic hepatic necrosis was noted after $\mathrm{CCl}_{4}$ and paracetamol administration with the destruction of hepatic cells. EETV treatment to such $\mathrm{CCl}_{4}$ and paracetamol intoxicated rats showed recovery of the hepatocytes from necrosis. This additionally recommends that the plant extract has a tremendous potential to reverse the changes induced by paracetamol toxicity.

The efficacy of EETV was dose-dependent, as confirmed by gradual decline of values. This may most likely to be, through activation of antioxidative enzymes by which hepatocytes structural and functional

Table 1: Effect of the Whole plant of EETV on biochemical liver enzymes against $\mathrm{CCl}_{4}$ induced hepatotoxicity in albino rats.

\begin{tabular}{ccccc}
\hline Treatment & $\begin{array}{c}\text { SGOT/ } \\
(\mathrm{U} / \mathrm{L})\end{array}$ & $\begin{array}{c}\text { SGPT/ } \\
(\mathrm{U} / \mathrm{L})\end{array}$ & $\begin{array}{c}\text { ALP } \\
(\mathrm{U} / \mathrm{L})\end{array}$ & $\begin{array}{c}\text { Bilirubin-Direct } \\
(\mathrm{mg} / \mathrm{dL})\end{array}$ \\
\hline Normal & $85.67 \pm 1.926$ & $101.2 \pm 4.126$ & $122.5 \pm 1.945$ & $1.231 \pm 0.0292$ \\
$\mathrm{CCL}_{4} 1.25 \mathrm{ml} / \mathrm{kg}$ P. O & $246.7 \pm 3.499^{* * *}$ & $293.5 \pm 3.160 \# \#$ & $247.5 \pm 3.149 \# \# \#$ & $3.942 \pm 0.0808 \# \# \#$ \\
Silymarin $100 \mathrm{mg} / \mathrm{kg}$ P.O. & $113.7 \pm 2.275^{* * *}$ & $127.8 \pm 3.070^{* * *}$ & $123.5 \pm 1.648^{* * *}$ & $1.499 \pm 0.0735^{* * *}$ \\
EETV $200 \mathrm{mg} / \mathrm{kg}$ P.O. & $151.5 \pm 3.052^{*}$ & $172.2 \pm 2.372^{* *}$ & $167.5 \pm 2.487^{*}$ & $2.399 \pm 0.115^{* *}$ \\
EETV $400 \mathrm{mg} / \mathrm{kg}$ P.O. & $124.5 \pm 2.029^{* *}$ & $135.3 \pm 2.616^{* * *}$ & $133 \pm 2.472^{* * *}$ & $1.529 \pm 0.0996^{* * *}$ \\
\hline
\end{tabular}

The values expressed as Mean + SEM, where $n=6$, All the data were analyzed by using one-way ANOVA followed by Tukey's test. \#\# $P<0.001$ significantly different from the normal group. ${ }^{\star} P<0.05 ;{ }^{*} P<0.01$ and ${ }^{* *} P<0.001$ significantly different to hepatotoxic group $\left(\mathrm{CCl}_{4}\right.$ treatment). 
Table 2: Effect of the Whole plant of EETV on biochemical liver enzymes against Paracetamol induced hepatotoxicity in rats.

\begin{tabular}{ccccc}
\hline Treatment & $\begin{array}{c}\text { SGOT } \\
(\mathrm{U} / \mathrm{L})\end{array}$ & $\begin{array}{c}\text { SGPT } \\
(\mathrm{U} / \mathrm{L})\end{array}$ & $\begin{array}{c}\text { ALP } \\
(\mathrm{U} / \mathrm{L})\end{array}$ & $\begin{array}{c}\text { Bilirubin-Direct } \\
(\mathrm{mg} / \mathrm{dL})\end{array}$ \\
\hline Normal & $88.60 \pm 2.462$ & $61.60 \pm 2.358$ & $107.4 \pm 1.778$ & $0.2056 \pm 0.01683$ \\
Paracetamol 1 gm/kg P. O & $313.2 \pm 3.338^{\# \# *}$ & $2.948 \pm 3.308 \# \# \#$ & $261.4 \pm 3.803 \# \# \#$ & $2.970 \pm 0.09259 \# \# \#$ \\
Silymarin $100 \mathrm{mg} / \mathrm{kg}$ P.O. & $111.6 \pm 2.272^{* * *}$ & $70.00 \pm 1.703^{* * *}$ & $115.6 \pm 2.400^{* * *}$ & $0.8578 \pm 0.1291^{* * *}$ \\
EETV $200 \mathrm{mg} / \mathrm{kg}$ P.O. & $176.4 \pm 5.802^{*}$ & $139.4 \pm 3.628^{* *}$ & $170.8 \pm 2.131^{*}$ & $1.612 \pm 0.1535^{* *}$ \\
EETV 400 mg/kg P.O. & $130.6 \pm 2.839^{* *}$ & $81.80 \pm 2.973^{* * *}$ & $129.2 \pm 1.241^{* * *}$ & $0.9426 \pm 0.08626^{* * *}$ \\
\hline
\end{tabular}

The values expressed as Mean + SEM where $n=6$. All the data were analyzed by using one-way ANOVA followed by Tukey's test. \#\#\# $P<0.001$ significantly different to the normal group. ${ }^{*} P<0.05 ;{ }^{*} P<0.01$ and ${ }^{* *} P<0.001$ significantly different to hepatotoxic group (Paracetamol treatment).

\begin{tabular}{|c|c|c|c|}
\hline Treatment & $\begin{array}{c}\text { GSH } \\
\text { ( } \mu \mathrm{g} / \mathrm{mg} \text { protein) }\end{array}$ & $\begin{array}{c}\text { CATALASE } \\
\text { (U/mg protein) }\end{array}$ & $\begin{array}{c}\text { LPO } \\
\text { (nM MDA/mg protein) }\end{array}$ \\
\hline Normal & $1.391+0.0180$ & $3.429+0.1649$ & $1.281+0.0227$ \\
\hline $\mathrm{CCL}_{4} 1.25 \mathrm{ml} / \mathrm{kg}$ P. O & $0.6128+0.0985^{\# \# \#}$ & $1.401+0.0833^{\# \# \#}$ & $3.744+0.1460^{\# \# \#}$ \\
\hline Silymarin 100 mg/kg P.O. & $1.368+0.0495^{* *+}$ & $3.182+0.0841^{* * *+}$ & $1.396+0.03571^{* * *}$ \\
\hline EETV 200 mg/kg P.O. & $1.202+0.0168^{* *}$ & $2.211+0.0972^{*}$ & $2.068+0.0664$ \\
\hline EETV 400 mg/kg P.O. & $1.322+0.0134^{* *+*}$ & $3.090+0.1341^{* * *+}$ & $1.664+0.0687^{* *}$ \\
\hline
\end{tabular}

The values expressed as Mean + SEM where $n=6$. All the data were analyzed by using one-way ANOVA followed by Tukey's test. \#\#\# $P<0.001$ significantly different from the normal group. ${ }^{\star} P<0.05$; ${ }^{* *} P<0.01$ and ${ }^{* * *} P<0.001$ significantly different to hepatotoxic group $\left(\mathrm{CCl}_{4}\right.$ treatment).

\begin{tabular}{|c|c|c|c|}
\hline Treatment & $\begin{array}{c}\text { GSH } \\
\text { ( } \mu \mathrm{g} / \mathrm{mg} \text { protein) }\end{array}$ & $\begin{array}{c}\text { CATALASE } \\
\text { (U/mg protein) }\end{array}$ & $\begin{array}{c}\text { LPO } \\
\text { (nM MDA/mg protein) }\end{array}$ \\
\hline Normal & $0.9586+0.05199$ & $4.115+0.1926$ & $0.2178+0.002311$ \\
\hline Paracetamol 1 gm $/ \mathrm{kg}$ P. O & $0.4908+0.008470^{\# \# \#}$ & $1.340+0.1622^{\# \# \#}$ & $0.5886+0.02772^{\# \# \#}$ \\
\hline Silymarin 100 mg/kg P.O. & $0.8920+0.05623^{* * *}$ & $3.594+0.2045^{+x * x}$ & $0.2488+0.01125^{* * *}$ \\
\hline EETV 200 mg/kg P.O. & $0.6752+0.01549^{* *}$ & $2.267+0.03893^{*}$ & $0.3380+0.01354^{*}$ \\
\hline EETV 400 mg/kg P.O. & $0.8320+0.04019^{* * *}$ & $3.390+0.1820^{*+* *}$ & $0.2824+0.01551^{* *}$ \\
\hline
\end{tabular}

The values expressed as Mean + SEM where $n=6$. All the data were analyzed by using one-way ANOVA followed by Tukey's test. \#\#\# $P<0.001$ significantly different to the normal group. ${ }^{*} P<0.05$; ${ }^{* *} P<0.01$ and ${ }^{* *} P<0.001$ significantly different to hepatotoxic group (Paracetamol treatment)

integrity of the liver restores. Treatment with EETV extract being able to mitigate leakages of marker enzymes into circulation and fasten the recovery of parenchymal cells. ${ }^{23}$ It has been reported that Bauhinia racemose contains flavonoids, triterpenoids, and steroids ${ }^{24}$ and many scientific reports indicated all these have a protective effect on the liver due to their antioxidant properties. ${ }^{25,26}$ To the end, the presence of those compounds in EETV also may be responsible for the protective effect on $\mathrm{CCl}_{4}$ and Paracetamol-induced liver damage in rats.

\section{CONCLUSION}

The present study demonstrates that the whole plant of EETV has a potent hepatoprotective action on carbon tetrachloride and paracetamol- induced hepatotoxicity in rats. The phytochemical analysis revealed the presence of flavonoids, tannins, and phenols. Our results showed that the hepatoprotective effect of the whole plant of EETV at a dose of $400 \mathrm{mg} / \mathrm{kg}$ significantly, compare to $200 \mathrm{mg} / \mathrm{kg}$. This may be due to its flavonoids, tannins, phenols, and antioxidant properties. The histopathological assessment of $\mathrm{CCL}_{4}$ and Paracetamol does prove the same. To conclude that Tephrosia villosa whole plant extract can effectively suppress the $\mathrm{CCl}_{4}$ and paracetamol-induced hepatotoxicity in albino rats, suggesting the potential protective role in various liver diseases. Further, studies are required to isolate, characterize and find out the mechanism of action of the active compounds in the whole plant of EETV responsible for hepatoprotective activity. 


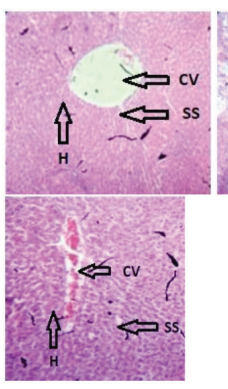

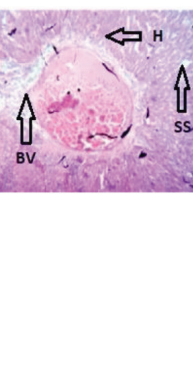

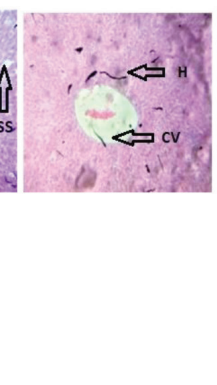

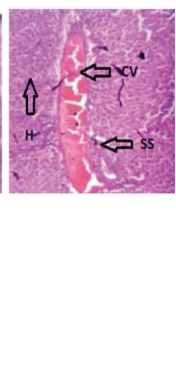

(D)
(A)

(B)

(C)

(E)

CV - Central vein $\mathbf{H}$ - Hepatocytes; SS - Sinusoidal spaces BV - Blood vessels

Figure A: Normal group that received CMC for seven days has shown normal architecture of hepatic cells with the normal central vein (CV).

Figure B: $\mathrm{CMC}$ for seven days, $\mathrm{CCl}_{4} 1.25 \mathrm{ml} / \mathrm{kg}$, and paracetamol $1 \mathrm{gm} / \mathrm{kg} / \mathrm{P} . \mathrm{O}$ for single-dose has shown centrilobular degeneration and necrosis of hepatic cells with dilated blood vessels.

Figure C: Silymarin $100 \mathrm{mg} / \mathrm{kg}$ for seven days, $\mathrm{CCl}_{4} 1.25 \mathrm{ml} / \mathrm{kg}$, and paracetamol $1 \mathrm{gm} / \mathrm{kg} /$ P.O for single dos has shown complete regeneration and normal architecture of hepatocytes, similar to that of the vehicle-treated group.

Figure D: EETV $200 \mathrm{mg} / \mathrm{kg}$ for 7 days, $\mathrm{CCl}_{4} 1.25 \mathrm{ml} / \mathrm{kg}$ and paracetamol $1 \mathrm{gm} / \mathrm{kg} / \mathrm{P}$.O for single dose has shown moderate regeneration reverting to hepatocytes

Figure E: EETV $400 \mathrm{mg} / \mathrm{kg}$ for seven days, $\mathrm{CCl}_{4} 1.25 \mathrm{ml} / \mathrm{kg}$, and paracetamol $1 \mathrm{gm} / \mathrm{kg} /$ P.O for single-dose has shown most regeneration and almost normal architecture of hepatocytes.

\section{ACKNOWLEDGEMENT}

This work was supported by Creative Educational Society's College of Pharmacy, Kurnool, Andhra Pradesh.

\section{CONFLICT OF INTEREST}

We declare that we have no conflict of interest.

\section{REFERENCES}

1. Law K, Brunt EM. Nonalcoholic fatty liver disease. Clin Liver Dis. 2010;14(4):591-604. doi: 10.1016/j.cld.2010.07.006.

2. Stickel F, Schuppan D. Herbal medicine in the treatment of liver diseases. Dig Liver Dis. 2007;39(4):293-304. doi: 10.1016/j.dld.2006.11.004, PMID 17331820

3. Martin I, Grotewiel MS. Oxidative damage and age-related functional declines. Mech Ageing Dev. 2006;127(5):411-23. doi: 10.1016/j.mad.2006.01.008, PMID 16527333

4. Kataki MS, Ahmad MZ, Awasthi D, Tomar B, Mehra P, Yadav RS, Rajak P. In vitro antioxidant profile of Wedeliacalandulaceae leaves. Pharmacologia. 2012;3(3):75-83. doi: 10.5567/pharmacologia.2012.75.83.

5. Feijóo M, Túnez I, Ruiz A, Tasset I, Muñoz E, Collantes E. Oxidative stress biomarkers as indicator of chronic inflammatory joint diseases stage. Reumatol Clin. 2010;6(2):91-4. doi: 10.1016/j.reuma.2008.12.016, PMID 21794688.

6. Klaunig JE, Wang Z, Pu X, Zhou S. Oxidative stress and oxidative damage in chemical carcinogenesis. Toxicol Appl Pharmacol. 2011;254(2):86-99. doi: 10.1016/j.taap.2009.11.028, PMID 21296097.

7. Radak Z, Zhao Z, Goto S, Koltai E. Age-associated neurodegeneration and oxidative damage to lipids, proteins and DNA. Mol Aspects Med. 2011;32(4-6):305-15. doi: 10.1016/j.mam.2011.10.010, PMID 22020115.

8. Wang N, Li P, Wang Y, Peng Y, Wu I. Hepatoprotective effect of Hypricumjaponicum extract and its function. J Ethnopharmacol. 2006;116:1-6.

9. Nallamilli BR, Kumar C, Reddy SP V, M. L. Prasannac, V. Maruthi, P. Sucharit, Hepatoprotective activity of Cichorium intybus (Linn.) root extract against carbon tetrachloride induced hepatotoxicity in albino Wistar rats, Drug Invent Today. 2013;5:311-314

10. Navarro VJ, Senior JR. Drug-related hepatotoxicity. $N$ Engl J Med. 2006;354(7):731-9. doi: 10.1056/NEJMra052270.

11. Demirdag K, Bahcecioglu IH, Ozercan IH, Ozden M, Yilmaz S, Kalkan A. Role

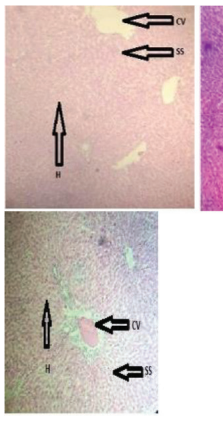

(A)

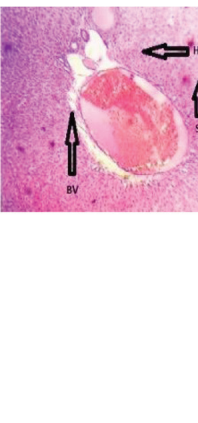

(B)

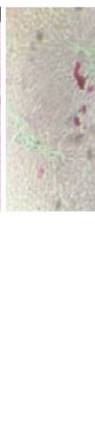

(C)

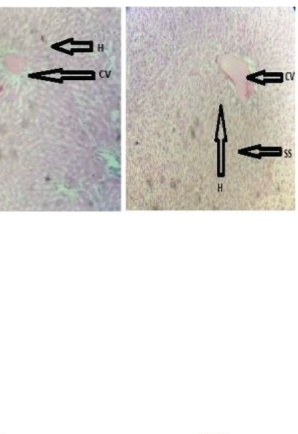

(D)
Figure 2: EETV+ Paracetamol treated albino rats.

Figure A: Normal group that received CMC for seven days has shown normal architecture of hepatic cells with the normal central vein (CV).

Figure B: CMC for seven days, $\mathrm{CCl}_{4} 1.25 \mathrm{ml} / \mathrm{kg}$, and paracetamol $1 \mathrm{gm} / \mathrm{kg} /$ P.O for single-dose has shown centrilobular degeneration and necrosis of hepatic cells with dilated blood vessels.

Figure C: Silymarin $100 \mathrm{mg} / \mathrm{kg}$ for seven days, $\mathrm{CCl}_{4} 1.25 \mathrm{ml} / \mathrm{kg}$, and paracetamol $1 \mathrm{gm} / \mathrm{kg} /$ P.O for single dos has shown complete regeneration and normal architecture of hepatocytes, similar to that of the vehicle-treated group.

Figure D: EETV $200 \mathrm{mg} / \mathrm{kg}$ for 7 days, $\mathrm{CCl}_{4} 1.25 \mathrm{ml} / \mathrm{kg}$ and paracetamol $1 \mathrm{gm} / \mathrm{kg} /$ P.O for single dose has shown moderate regeneration reverting to hepatocytes

Figure E: EETV $400 \mathrm{mg} / \mathrm{kg}$ for seven days, $\mathrm{CCl}_{4} 1.25 \mathrm{ml} / \mathrm{kg}$, and paracetamol $1 \mathrm{gm} / \mathrm{kg} /$ P.O for single-dose has shown most regeneration and almost normal architecture of hepatocytes. of L-carnitine in the prevention of acute liver damage induced by carbon tetrachloride in rats. J Gastroenterol Hepatol. 2004;19(3):333-8. doi: 10.1111/j.14401746.2003.03291.x, PMID 14748882

12. Kshirsagar AD, Mohite R, Aggrawal AS, Suralkar UR. Hepatoprotective medicinal plants of Ayurveda-A review. Asian J Pharm Clin Res. 2011;4(3):1-8.

13. Shaik A, Elumalai A, Eswaraiah MC, Usha. An updated review on hepatoprotective medicinal plants. J Drug Deliv Ther. 2012;2(2):1-3.

14. OECD [guidelines]. 423 , acute oral toxicity: environmental health and safety monograph series on testing and assessment no. Environmental Directorate; 2000.

15. ChakaliAyyanna TBD, Rafiq Hussain G, Sudha Rani D, Madhan Mohan G, ShahanazKhatoon B, Sneha Reddy B. Evaluation of the hepatoprotective and antioxidant activity of ethanolic extract of Nerium indicum Mill. leaves against carbon tetrachloride-induced hepatotoxicity in albino rats. Int J Res Pharm Sci. 2018;9(4):1088-95.

16. Okokon JE, Simeon JO, Umoh EE. Hepatoprotective activity of the extract of Homalium letestui stem against paracetamol-induced liver injury. Avicenna J Phytomed. 2017;7(1):27-36. PMID 28265544.

17. Mokrasch LC, Teschke EJ. Glutathione content of cultured cells and rodent brain regions: a specific fluorometric assay. Anal Biochem. 1984 Aug 1;140(2):506-9 doi: 10.1016/0003-2697(84)90201-x, PMID 6486436.

18. wan $\mathrm{H}$. MH, abed HN. Data supporting the spectrophotometric method for the estimation of catalase activity. Data Brief. 2016;6:194.

19. Ohkawa H, Ohishi N, Yagi K. Assay for lipid peroxides in animal tissues by thiobarbituric acid reaction. Anal Biochem. 1979;95(2):351-8. doi: 10.1016/00032697(79)90738-3, PMID 36810.

20. Reyes-Gordillo K, Segovia J, Shibayama M, Vergara P, Moreno MG, Muriel P. Curcumin protects against acute liver damage in the rat by inhibiting NF-kappaB proinflammatory cytokines production and oxidative stress. Biochim Biophys Acta. 2007;1770(6):989-96. doi: 10.1016/j.bbagen.2007.02.004, PMID 17383825

21. Shechter $Y$. Trifluoperazine inhibits insulin action on glucose metabolism in fat cells without affecting inhibition of lipolysis. Proc Natl Acad Sci U S A. 1984;81(2):327-31. doi: 10.1073/pnas.81.2.327. PMID 6582491.

22. Recknagel RO, Glende EA, Dolak JA, Waller RL. Mechanisms of carbon tetrachloride toxicity. Pharmacology \& Therapeutics. 1989;43(1):139-54. doi: 10.1016/0163-7258(89)90050-8.

23. Friedman SE, Grendell JH, Quaid Mc KR. Current diagnosis and treatment in gastroenterology. New York: Lang Medical Books/McGraw-Hill; 2003. p. 664

24. Wei YH. Oxidative stress and mitochondrial DNA mutations in human aging. Proc Soc Exp Biol Med. 1998;217(1):53-63. doi: 10.3181/00379727-217-44205, PMID 9421207. 
25. Halliwell B, Gutteridge JM, Cross CE. Free radicals, antioxidants, and human disease: where are we now? JLab. Clin Mediterr. 1992;119:598-620.
26. Kurata M, Suzuki M, Agar NS. Antioxidant systems and erythrocyte life-span in mammals. Comp Biochem Physiol B. 1993;106(3):477-87. doi: 10.1016/03050491(93)90121-k. PMID 8281748.

Article History: Received: 06-06-2021; Revised: 19-07-2021; Accepted: 02-09-2021

Cite this article: Ayyanna C, Mounika B, Sudha STY, PugazhenthanThangaraju. Assessment of Hepatoprotective and Antioxidant Activities of Ethanolic Extract of Tephrosia villosa in Albino Rats. J Young Pharm. 2021;13(3):229-34. 